\title{
Potassium as an Essential Nutrient for Citrus Plant: A Review
}

\section{Muhammad Danish Toor ${ }^{1}$, Aqarab Husnain Gondal' ${ }^{2 *}$, Muhammad Shozib Javid ${ }^{3}$, Muhammad Waqas Ashraf ${ }^{3}$, Irfan Hussain ${ }^{1}$, Abu Bakar Ijaz $^{1}$ and Dua-e-Zainab ${ }^{1}$}

${ }^{1}$ European University of Lefke, Institute of Graduate Studies and Research, Department of Environmental Sciences Northern, Cyprus, Turkey

${ }^{2}$ Institute of Soil and Environmental Sciences, University of Agriculture, Pakistan

${ }^{3}$ Czech University of Life Sciences, Czech Republic

*Corresponding Author: Aqarab Husnain Gondal, Institute of Soil and

Environmental Sciences, University of Agriculture, Pakistan.
Received: May 28, 2021

Published: June 24, 2021

(C) All rights are reserved by Aqarab Husnain Gondal., et al.

\begin{abstract}
Different types of nutrients are necessary for the growth of plants. These nutrients are the source of food for plants and play an essential role in their development. Furthermore, macronutrients and micronutrients are the two groups in which these nutrients are classified. Macro means "large", so macronutrients deal with those nutrients that are needed in large amounts. Similarly, Micro means "small", so micronutrients deal with those nutrients that are required in small quantities. Potassium is fall in the category of macronutrients. It is highly mobile in plants from the individual cell to xylem and phloem tissues. It plays an essential role in fruit crops. Potassium is the most significant nutrient which regulates the value of fruits through its influence on the size of fruit, appearance of the fruit, fruit color, and vitamin contents. Other hands, Citrus fruits are those fruits that comprise enough amount of citric acid. The main Citrus fruits are oranges, lemons, beets, tomatoes, and they all are categorized as acid fruits. The applications of potassium fertilizers are vital for the better production of Citrus plants. This review article focuses on potassium (K), its role, its applications for Citrus plant.
\end{abstract}

Keywords: Potassium; Macronutrients; Citrus; Fruit Crops; Applications

\section{Introduction}

The growth and development of plants are dependent on the source of the nutrients. Plants need a different type of nutrients. These nutrients are categorized into two groups, i.e. macronutrients and micronutrients, according to their requirements. These nutrients include nitrogen $(\mathrm{N})$, phosphorous $(\mathrm{P})$, potassium $(\mathrm{K})$, calcium (Ca), zinc (Zn), iron (Fe), boron (B), sulphur (S), magnesium (Mg) etc. In the body of a plant, many biochemical processes influence by nutrients and provide resistance. According to the de- creasing trend in crop yields and fast increasing in the world population, food safety is the main challenge $[5,17,18]$ of Well-adjusted nutrients application is very important to increase crop yield and attain the necessary rise in food production. Additionally, nutrients play a significant role in soil fertility and make it more productive for plant growth [21].

Potassium is often considered as the quality element for the production of a crop. Moreover, plant growth and supporting high 
yield in agriculture K are essential nutrients [23]. For ATP production, plants need $\mathrm{K}$ produced in transpiration and photosynthesis processes. Potassium's vital importance and role are performed in the form of its ability to stimulate the synthesis of photosynthates and improvement in the alteration in oil, starch, protein, vitamins, etc. [11]. In chloroplasts, it keeps the stability of electric charges, which is essential for ATP formation. Applications of $\mathrm{K}$ in large amount will stabilize the $\mathrm{pH}$ by counterbalance the insoluble and soluble macromolecular anions [8].

Another hand, Citrus is one of the most significant tree crops $[6,16]$ and a wide range of potassium content in the leaves is required for the average vegetative growth of Citrus [20]. The amount of $\mathrm{K}$ below $0.4 \%$ affects tree development; otherwise, over an extensive range of variation does not generally affect tree growth [15]. In the subtropical area, the bulk of the total global production of the best quality fruit is produced. According to research, about 102 million metric tons of Citrus have been made per year globally, far superior to other subtropical and tropical fruits. For example, joining the production of orange in the United States and Brazil accounts for $45 \%$ of the entire world [2]. Also, Citrus is a vital fruit crop in many countries. Citrus sinensis L. Osbeck is one of the most standard Citrus fruit for its delightful taste and rich in minerals and vitamin $\mathrm{C}$.

\section{Classification of Citrus}

Genus Citrus belongs to the large family Rutaceae, which contains 130 genera in the 7 subfamilies with several significant fruit and vital oil producers [7]. Classification of Citrus as shown in table 1 (http://en.wikipedia.org/wiki/lemon).

\begin{tabular}{|l|c|}
\hline \multicolumn{1}{|c|}{ Kingdom } & Plantae \\
\hline Division & Magnoliophyta \\
\hline Class & Magnoliopsida \\
\hline Subclass & Rosidae \\
\hline Order & Sapindales \\
\hline Family & Rutaceae \\
\hline Genus & Citrus \\
\hline
\end{tabular}

Table 1: Classification of citrus plants.

\section{History of potash}

Throughout Colonial eras, for manufacturing soap, people burned timber and other organic matter in pots. After that, burned ashes were soaked and then they allowed water to disappear. In the end, a residue of $\mathrm{K}$ salts has been left behind. People named those remains "potashes", which transfer into the word potash. Furthermore, the letter $\mathrm{K}$ is used to denote $\mathrm{K}$ that originates from the German word Kalium. Animal fats are also used to produce soap with these salts. A botanist in Connecticut, Samuel William Jackson, analyzed the ash by burning plants in 1868 . He found large quantities of $\mathrm{K}$ in burning residues of plants with many other mineral deposits. After his work, potash fertilisers have been promoted as a main source for increasing crop [9].

Presences of potassium in soil

In the soil, there are four different potassium sources present. Soil minerals such as feldspar and mica are the most significant soil component of K. For the use of the plant, a very slight amount of this $\mathrm{K}$ source is available. The non-exchangeable $\mathrm{K}$ is the second source that is present in the soil. Furthermore, $\mathrm{K}$ is associated with the 2:1 clay minerals. On the earth, the non-exchangeable source of $\mathrm{K}$ acts as a source of the reserve source. The third source of soil $\mathrm{K}$ is called the readily available $\mathrm{K}$. It is set up on the cation exchange sites.

\section{Role of potassium in Citrus plants}

Citrus trees' seasonal absorption of $\mathrm{K}$ is deficient during the colder months and quickly increases until new growth and bloom begin in the spring [29]. Furthermore, nitrogen and $\mathrm{K}$ in the fruits account for most of the nutrients removed from the soil by the tree each year. It plays a significant role in root growth enhancement, drought tolerance, decreasing water loss and wilting, improving pest and disease resistance, and reducing stalk lodging [30]. Also, in Citrus trees, it plays a critical role. In trees, the $\mathrm{K}$ requirement is ranged from 0.5 to $2 \%$ of dry matter, which is next to that for $\mathrm{N}$. When the $\mathrm{K}$ level is in the ideal range, then the satisfactory yield of the fresh fruit can be attained.

Moreover, an element has leading effects on the qualities of fruit both externally and internally, including production, size, color, roughness and acidity (yerner@volcani.agri.gov.il). Besides, other nutrients, such as calcium, are abundant in plants' skeletal matrix, which is made up of woody tissue and old leaves. Many phenomena, including both visible and invisible, may be affected by $\mathrm{K}$ in Citrus plants. All the issues such as increasing or decreasing $\mathrm{pH}$ and other processes significantly influence soil nutrients, especially $\mathrm{K}$ and ultimately affect the growth, yield and quality of Citrus fruits plants [27,28,33-36]. 
Effects of potassium on fruit quality

$\mathrm{K}$ is vital for maintaining cell turgor and extensibility, which influences fruit size. $\mathrm{K}$ is present in high amounts in growing sections such as leaves, flowers, and fruits because it is highly mobile in plants. Except, when leaf K concentrations drop below 3 - $4 \mathrm{mg} / \mathrm{kg}$, Citrus trees do not exhibit noticeable deficiency symptoms across a broad spectrum of K status in the leaves. Fruit consistency, on the other hand, is highly susceptible to fluctuations in K supply. Fruit production, as well as fruit quality, is all affected by the $\mathrm{K}$ diet. External fruit properties are affected by K, including fruit weight, green fruit, and size and peel thickness. Besides, fruit deterioration leads to economic losses as well. According to various epidemiologists, it has been demonstrated that consumption of Citrus fruit is defensive in a variety of cancers in human and several more diseases. Likewise, Citrus maxima is the primary Citrus fruit with beneficial properties related to medicine [31]. There are many important sources of such vital nutrients $(\mathrm{K}, \mathrm{Ca})$ in Citrus fruits, containing grapefruits, oranges, and lemons recommended for the anticipation of degenerative disease.

On the other hand, Citrus fruits contain a wide range of phytochemicals, folic acid, vitamins $\mathrm{C}$, carotenoids, dietary fibers, and selenium [19]. Increases plant protein content, increases starch content, increases vitamin $\mathrm{C}$ and solid soluble content, enhances fruit color and taste are some of the fundamental effects of $\mathrm{K}$ on quality improvement. Fruit size is increased, peel thickness is increased, physiological disorders are reduced, insect and disease occurrence is decreased, storage and shipping consistency is improved, and shelf life is extended [30].

\section{Citrus and citric acid}

Citric acid is found in Citrus fruits and not an organic solid tricarboxylic acid. Its chemical formula is $\left(\mathrm{C}_{6} \mathrm{H}_{8} \mathrm{O}_{7}\right)$. Lemons, oranges, tomatoes, and beets are the main Citrus fruits classified as acid fruits. Because these fruits contain a sufficient amount of citric acid. Citric acid is a natural integral and metabolite of animals and plants.

Furthermore, it is a valid and extensively used organic acid in pharmaceuticals and food businesses. In taste, Citric acid is acidic and an excellent preserving agent too. Citric acid is soluble and can be manufactured easily. The fruit stability can be increased by Citric acid, and it is used in flavoring agent [3,32]. The economic potential of Citric acid is high due to its many applications. Accord- ing to many researchers, the production of citric acid is very useful due to its many applications, especially in medications, foods, and manufacturing. It is a weak organic acid that ensues naturally in several fruits and vegetables, particularly in Citrus fruits [12].

\section{Potassium as a fertilizer}

According to Boman and Obreza [1] $\mathrm{K}$ is one of the primary nutrients for Citrus plants. Major potassium sources include $\mathrm{KCl}$ which is called potassium chloride, $\mathrm{KNO}_{3}$ as potassium nitrate, and $\mathrm{K}_{2} \mathrm{SO}_{4}$ as potassium sulfate, respectively. Potassium may produce solid precipitants when it mixed with other fertilizers. Other hands, the $\mathrm{K}_{2} \mathrm{SO}_{4}$ solubility is minimal. That's why chemigation seldom has been used. Another common source of $\mathrm{K}$ is Potassium thiosulfate, which can be mixed with ammonium polyphosphate solutions and urea in the deficiency of acidic fertilizers. The primary K sources are presented below in table 2 , along with their merits and demerits.

\begin{tabular}{|c|c|c|}
\hline Source & Merit & Demerit \\
\hline $\begin{array}{l}\text { Potassium } \\
\text { chloride }\end{array}$ & $\begin{array}{l}\mathrm{KCl} \text { is one of the least } \\
\text { expensive. } \\
\text { Most popular } \\
\text { Highly water-soluble } \\
\text { fertilizer }\end{array}$ & $\begin{array}{l}\text { Not applicable if the ir- } \\
\text { rigation water contains } \\
\text { high levels of salinity. }\end{array}$ \\
\hline $\begin{array}{l}\text { Potassium } \\
\text { nitrate }\end{array}$ & $\begin{array}{l}\mathrm{KNO}_{3} \text { is an expensive } \\
\text { fertilizer component } \\
\text { compared with other } \mathrm{K} \\
\text { sources. } \\
\text { For areas of high saline } \\
\text { irrigation water, it is an } \\
\text { excellent choice of } \\
\text { potassium fertilizers }\end{array}$ & $\begin{array}{l}\text { It is less soluble than } \\
\text { KCl. }\end{array}$ \\
\hline $\begin{array}{l}\text { Potassium } \\
\text { sulfate }\end{array}$ & $\begin{array}{l}\mathrm{K}_{2} \mathrm{SO}_{4} \text { is one of the best } \\
\text { replacements for } \mathrm{KCl} \text { in } \\
\text { high salinity areas }\end{array}$ & $\begin{array}{l}\text { It is less soluble than } \\
\text { both } \mathrm{KCl} \text { and } \mathrm{KNO}_{3} \text {. }\end{array}$ \\
\hline
\end{tabular}

Table 2: Fertilizer sources of K among advantages and disadvantages.

\section{Conclusion}

Potassium is very significant in various ways for the production of the plant. In the growth and productivity of tree, it plays a critical role. We can increase the quality of fruit and the exhibition by the 
proper applications of potassium fertilizers. It also deals with the medicinal benefits and provides resistance against many diseases. It plays an essential role in fruit crops. It is the most crucial nutrient which regulating the quality of fruits.

\section{Bibliography}

1. Boman. "Fertigation Nutrient Sources and Application Considerations for Citrus". IFAS Circular 1410, University of Florida, Gainesville, FL, (2002): 14

2. FAO. Food and Agriculture Organization. "Faostat-Statistical databases" (2004).

3. Hotha., et al. "Development of betterquality assay method for the citric acid and sodium citrate in ophthalmic/oral solutions and their application to deformulation studies". American Journal of Analytical Chemistry 5.17 (2014): 1249.

4. http://en.wikipedia.org/wiki/lemon

5. Kalsoom M., et al. "Biological Importance of Microbes in Agriculture, Food and Pharmaceutical Industry: A review". Innovare Journal of Life Sciences 8.6 (2020).

6. Lagoda PJL. "Plant Breeding and Genetic Newsletter". FAOIAEA. (2007)

7. Lucker J., et al. "Biosynthesis in lemon (Citrus limon)". European Journal of Biochemistry 269 (2002): 3160-3171.

8. Marschner H. "Mineral nutrition of higher plants". Second edition. Academic Press. London, UK (1995).

9. McAfee J. "Potassium. A Key Nutrient for Plant Growth". Department of Soil and Crop Sciences (2008).

10. Bakar Ijaz S., et al. "Alleviation of zinc deficiency from humans through plants by organic sources". A Powerful Tonic. IJAR 4 (2021): 240-243.

11. Mengel K and Kirkby EA. "Principles of Plant Nutrition". 4th Edition. International Potash Institute, IPI, Bern, SMntzerland (1987). 685.

12. Nitin G., et al. "A Review on Citric Acid Production And its Applications". International Journal of Current Advanced Research 09 (2017): 5880-5883.
13. Fluger R and Menge, K P. "Antimd Soil" 36 (1972): 417-425.

14. Erner Y., et al. "Potassium Affects Citrus Tree Performance". The Volcani Center, Institute of Horticulture, Department of Fruit Trees, P.O. Box 6, Bet Dagan 50250, Israel.

15. Rees RL and Koz RCJ. "N and K fertilization effects on leaf analysis, tree size and yield of three major foliar orange cultivars". Journal of the American Society of Horticultural Science 100 (1975): 195-198.

16. Rehman F., et al. "Huanglongbing (HLB) As Citrus Devastating Disease: A Technical Report". SunText Review of Biotechnology 3 (2020c): 113.

17. Rehman F U., et al. "Plant Growth Promoting Rhizobacteria and their Mechanisms Involved in Agricultural Crop Production: A Review". SunText Review of Biotechnology. 1 (2020b): 1-6.

18. Rehman F., et al. "Chemistry of Plant-Microbe Interactions in Rhizosphere and Rhizoplane". Indian Journal of Pure and Applied Biosciences 5 (2020a): 11-19.

19. Silalahi J. "Anticancer and health protective properties of Citrus fruit components". Asia Pacific Journal of Clinical Nutrition. 1 (2002): 79-84.

20. Smith PF. "Citrus nutrition". In: Nutrition of fruit crops (Ed.: N.F. Childers). Horticultural Publications, Rutgers, New Brunswick, N.J. (1966).

21. Toor MD., et al. "Nutrients and Their Importance in Agriculture Crop Production; A Review". Indian Journal of Pure and Applied Biosciences 1 (2021): 1-6.

22. Trupti P., et al. International Journal of Recent Scientific Research 8 (2017): 19400-19416

23. Usherwood NR. In: PotaSSium in Agriculture. (Munson, R.S. ed.). ASA-CSSA-SSSA, Madison, WI (1985): 489-513.

24. Vandenberghe., et al. "Microbial production of citric acid". Brazilian Archives of Biology and Technology 42.3 (1999): 263276.

25. Vashist HE., et al. "A report on percentage yields of calcium citrate from citrus fruits and hydrodistillation of dried or- 
ange peel and cinnamon bark powder". International Journal of Pharmacy and Pharmaceutical Sciences 5 (2013): 401403.

26. Wallingford W. In: Potassium for Agriculture. Potash and Phosphate Institute, Atlanta, GA (1980): 10-27

27. Gondal A H., et al. "A Detailed Review Study of Zinc Involvement in Animal, Plant and Human Nutrition". Indian Journal of Pure and Applied Biosciences. 9.2 (2021a). 262-271.

28. Gondal HA., et al. "Influence of Soil Ph and Microbes on Mineral Solubility and Plant Nutrition: A Review" International Journal of Agriculture and Biological Sciences 5.1 (2021b): 71-81.

29. Alva A., et al. "Potassium management for optimizing citrus production and quality". International Journal of Fruit Science 6.1 (2006): 3-43.

30. Ramesh K A., et al. "Role of potassium in fruit crops-a review”. Agricultural Reviews 27.4 (2006): 284-291.

31. Ademosun A., et al. "Shaddock (Citrus maxima) peels extract restores cognitive function, cholinergic and purinergic enzyme systems in scopolamine-induced amnesic rats". Drug and Chemical Toxicology (2020): 1-8.

32. Vandenberghe L P., et al. "Comparison of citric acid production by solid-state fermentation in flask, column, tray, and drum bioreactors". Applied Biochemistry and Biotechnology 118.1 (2004): 293-303.

33. Gondal HA., et al. "Adaptability of soil $\mathrm{pH}$ through innovative microbial approach". Current Research in Agricultural Sciences 8.2 (2021): 71-79.

34. Bisma I C., et al. "A Brief Correspondence on Glyphosate Remediation using Microbes and Mineral Sources". Annual Reviews 6.4 (2021): 555693.

35. Aqarab Husnain Gondal., et al. "Alleviation of zinc deficiency from humans through plants by organic sources: A Powerful Tonic". International Journal of Applied Research 7.4 (2021): 240-243.
36. Haroon., et al. "Water Resources Helps İn The Expansion Of Mosquitoes Colonies". Big Data In Water Resources Engineering 1.1 (2021): 19-24.

Volume 5 Issue 7 July 2021

(C) All rights are reserved by Aqarab Husnain Gondal., et al. 